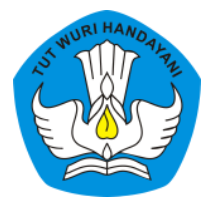

\title{
PEMBELAJARAN EDP-PROBLEM SOLVING PROJECT UNTUK MELATIH SISWA MENINGKATKAN KETERAMPILAN BERPIKIR KRITIS DAN PENYELESAIAN MASALAH
}

\author{
Dani Setiawan \\ Sekolah Menengah Pertama Negeri 1 Bulakamba - Kabupaten Brebes \\ Contributor Email: dani.setiawan@gmail.com
}

Published: Mar 30, 2020

Article Url: https:/ /ojsdikdas.kemdikbud.go.id/index.php/didaktika/article/view/147

\begin{abstract}
Indonesian students still need to strengthen their ability to integrate information, draw conclusions, and introduce their knowledge to other things. Indonesian students are still weak in answering questions with a level of reasoning. So the purpose of this study is to find out the critical thinking skills and problem solving of students in class VII.A SMPN 1 Bulakamba academic year 2018/2019 can be improved through learning EDP-Problem Solving Project. EDP-Problem Solving Project facilitates students to implement the engineering design process in conducting problem solving projects. EDP-Problem Solving Project learning activities consist of stages (1) ask (formulate questions), (2) imagine, (3) plan (plan), (4) creat (make), (5) test (try out), (6) analyze (analyze), (7) conclude (conclude), (8) communicate (communicate), and (9) improve (develop). The study was conducted with a class action research procedure. Data on critical thinking skills and problem solving are analyzed descriptively. The results showed that critical thinking skills and problem solving for students of class VII.A SMPN 1 Bulakamba in the 2018/2019 academic year could be improved through learning the EDP-Problem Solving Project.
\end{abstract}

Keywords: Learning, Critical thinking Skills, Problem Solving. 


\begin{abstract}
Abstrak
Siswa Indonesia masih perlu penguatan kemampuan mengintegrasikan informasi, menarik simpulan, serta menggenalisir pengetahuan yang dimiliki ke hal lain. Siswa Indonesia masih lemah dalam menjawab soal dengan level penalaran. Sehingga tujuan penelitian ini ntuk mengetahui keterampilan berpikir kritis dan penyelesaian masalah siswa pada kelas VII.A SMPN 1 Bulakamba tahun pelajaran 2018/2019 dapat ditingkatkan melalui pembelajaran EDP-Problem Solving Project. EDPProblem Solving Project memfasilitasi siswa mengimplementasikan engineering design process dalam melakukan proyek penyelesaian masalah. Aktivitas pembelajaran EDP-Problem Solving Project terdiri dari tahap (1) ask (merumuskan pertanyaan), (2) imagine (membayangkan), (3) plan (merencanakan), (4) creat (membuat), (5) test (mengujicobakan), (6) analyze (menganalisis), (7) conclude (menyimpulkan), (8) communicate (mengomunikasikan), dan (9) improve (mengembangkan). Penelitian dilakukan dengan prosedur penelitian tindakan kelas. Data keterampilan berpikir kritis dan penyelesaian masalah dianalisis secara deskriptif. Hasil penelitian menunjukkan bahwa keterampilan berpikir kritis dan penyelesaian masalah siswa kelas VII.A SMPN 1 Bulakamba tahun pelajaran 2018/2019 dapat ditingkatkan melalui pembelajaran EDP-Problem Solving Project.
\end{abstract}

Kata Kunci: Pembelajaran, Keterampilan Berpikir Kritis, Penyelesaian Masalah.

\title{
A. Pendahuluan
}

Memasuki era 21 menuntut setiap individu memiliki keterampilan unggul dan kompetetif. Dunia pendidikan memiliki tanggung jawab besar membekali siswa dengan keterampilan seiring dengan kemajuan teknologi. Guru menjadi garda terdepan yang terlibat langsung dalam upaya meningkatkan kemampuan siswa. Setiap guru memiliki kesempatan yang sama untuk membekali siswa dengan keterampilan kompetitif yang dikenal dengan istilah keterampilan abad 21, meliputi keterampilan berpikir kritis, keterampilan berpikir kreatif, keterampilan berkolaborasi, dan keterampilan berkomunikasi (Trilling \& Fadel, 2009; Häkkinen, et al., 2016; Roekel, 2018).

Beberapa hasil studi menunjukkan bahwa kemampuan berpikir siswa Indonesia pada jenjang pendidikan dasar masih tergolong rendah. Berdasarkan hasil survey TIMSS pada tahun 2015, peringkat sains siswa 
Indonesia hanya menempati peringkat 44 dari 47 negara (Martin, Mullis, Foy, \& Hooper, 2016).

Hasil survey tersebut mengindikasikan kemampuan berikir kritis siswa Indonesia masih rendah. Siswa Indonesia masih perlu penguatan kemampuan mengintegrasikan informasi, menarik simpulan, serta menggenalisir pengetahuan yang dimiliki ke hal lain. Siswa Indonesia masih lemah dalam menjawab soal dengan level penalaran. Untuk dapat mengerjakan soal penalaran, siswa dituntut memiliki kemampuan berpikir kritis yang baik. Hasil penelitian pada lingkup daerah oleh Fuad, Zubaidah, Mahanal, \& Suarsini (2015) mengungkapkan profil kemampuan berpikir kritis siswa di Kediri yang tergolong rendah.

Kelemahan dalam berpikir kritis juga dialami oleh siswa di SMPN 1 Bulakamba. Berdasarkan hasil tes prasiklus pada topik interaksi makhluk hidup dengan lingkungannya pada siswa kelas VII.A di SMPN 1 Bulakamba semester 2 tahun pelajaran 2018/2019 diperoleh rata-rata keterampilan berpikir kritis sebesar 49,06. Siswa yang mencapai skor di atas nilai kriteria ketuntasan minimal $(\mathrm{KKM}=70)$ hanya $6 \%$ atau 2 siswa dari 32 siswa. Hasil tes tersebut menunjukkan bahwa kemampuan berpikir kritis siswa di kelas VII.A SMPN 1 Bulakamba masih harus ditingkatkan.

Penyebab keterampilan berpikir kritis siswa di SMPN 1 Bulakamba yang masih rendah adalah siswa belum terfasilitasi dengan baik dalam berlatih berpikir kritis. Perhatian guru pada upaya peningkatan kemampuan berpikir kritis siswa masih belum maksimal. Hal ini sejalan dengan pendapat Fuad, Zubaidah, Mahanal, \& Suarsini (2015) yang menyatakan bahwa penyebab rendahnya keterampilan berpikir kritis karena upaya peningkatan kemampuan berpikir kritis belum ditangani dengan baik.

Fuad, Zubaidah, Mahanal, \& Suarsini (2017) menyatakan bahwa perbaikan kemampuan berpikir kritis siswa dapat dirancang melalui perencanaan pembelajaran yang melatih siswa berpikir kritis. Guru dapat membantu meningkatkan keterampilan berpikir kritis siswa melalui pembelajaran yang berpusat pada siswa (Mahanal, Zubaidah, Bahri, \& Dinnurriya, 2016). Kemampuan berpikir kritis juga dapat ditingkatkan 
melalui desain pembelajaran yang berorientasi pada penyelesaian masalah (Suarsana \& Mahayukti, 2013; Redhana, 2017).

Upaya untuk memperbaiki keterampilan berpikir kritis dan penyelesaian masalah siswa kelas VII-A SMPN 1 Bulakamba dapat dilakukan melalui pembelajaran yang menekankan pada proses penyelesaian masalah dan berpusat pada siswa. Ada beberapa aktivitas pembelajaran yang terbukti dapat membantu meningkatkan kemampuan menyelesaikan masalah dan keterampilan berpikir kritis, di antaranya adalah engineering design process (EDP), model problem base learning (PBL), dan model project base learning (PjBL). Pembelajaran EDP memiliki struktur dasar penyelesaian masalah yang dapat menuntun siswa menjadi perancang penyelesai masalah melalui proses menganalisis masalah, mensintesis sumber dan informasi ke dalam penyelesaian masalah, dan mengevaluasi penyelesaian masalah (Sutia \& Mahdalena, 2017).

Hasil studi Berland, Steingut, \& Ko (2014), Sutia \& Mahdalena (2017), dan Syukri, Soewarno, Halim, \& Mohtar (2018) yang menunjukkan bahwa penerapan pembelajaran EDP dapat membantu siswa meningkatkan kemampuan menyelesaikan masalah. Hasil studi menunjukkan bahwa $P B L$ dapat membantu siswa dalam meningkatkan keterampilan berpikir kritis dan menyelesaikan masalah (Simamora, Sidabutar, \& Surya, 2017; Sagala, Rahmatsyah, \& Simanjuntak, 2017; Herzon, Budijanto, \& Utomo, 2018; Ningsih, Hidayat, \& Kusairi, 2018). Penerapan PjBL juga berpengaruh terhadap peningkatan kemampun berpikir kritis siswa dan menyelesaikan masalah(Pratama \& Prastyaningrum, 2016; Hikmah, Budiasih, \& Santoso, 2016; Purnomo \& Mawarsari, 2014).

Berdasarkan uraian dampak positif implementasi EDP, $P B L$, dan $P j B L$ terhadap peningkatan kemampuan siswa dalam menyelesaikan masalah dan berpikir kritis, maka untuk memperbaiki keterampilan berpikir kritis dan penyelesaian masalah siswa kelas VII-A SMPN 1 Bulakamba dilakukan melalui pembelajaran EDP-Problem Solving Project. EDP-Problem Solving Project merupakan model pembelajaran yang memfasilitasi siswa mengimplementasikan engineering design process untuk melakukan proyek 
penyelesaian masalah. EDP-Problem solving project terdiri dari unsur problem solving (penyelesaian masalah) dan project (proyek). Aktivitas pembelajaran EDP-Problem Solving Project terdiri dari tahap (1) ask (merumuskanpertanyaan), (2) imagine (membayangkan), (3) plan (merencanakan), (4) creat (membuat), (5) test (mengujicobakan), (6) analyze (menganalisis), (7) conclude (menyimpulkan), (8) communicate (mengomunikasikan), dan (9) improve (mengembangkan). Penerapanpembelajaran EDP-Problem Solving Projectdiharapkan mampu membantu siswa dalam memperbaiki kemampuan berpikir kritis dan penyelesaian masalah.

Penerapan pembelajaran EDP-Problem Solving Project dilakukan pada topik pencemaran lingkungan dan difokuskan pada kegiatan siswa dalam menanggulangi pencemaran lingkungan yang bersumber dari pertanian bawang merah. Masalah pencemaran pertanian bawang ini sangat kontekstual bagi siswa SMPN 1 Bulakamba Kabupaten Brebes. Bawang merah merupakan identitas masyarakat Brebes dan salah satu sentra penghasilnyaberada di sekitar SMPN 1 Bulakamba, yaitu di Desa Banjaratma, Kecamatan Bulakamba.

Berdasarkan pemaparan di atas yang telah diuraikan, maka permasalahan penelitian yang akan dijawab yaitu untuk mengetahui keterampilan berpikir kritis penyelesaian masalah siswa kelas VII.A SMPN 1 Bulakamba pada materi pencemaran lingkungan dapat ditingkatkan melalui pembelajaran EDP-Problem Solving Project

Tentu saja manfaat dari penelitian yang dilakukan antara lain bahwa pembelajaran EDP-Problem Solving Project dapat menuntun siswa berlatih langsung dalam menyelesaikan masalah. Keterlibatan langsung siswa pada penyelesaian masalah akan melatih siswa berpikir kritis dan berdampak memberikan kontribusi pada peningkatan kualitas pembelajaran di sekolah secara umum.

\section{B. Metode}

Penelitian dilakukan melalui prosedur penelitian tindakan kelas yang terdiri dari 2 (dua) siklus. Tiap siklus dilakukan melalui empat tahap kegiatan utama, yaitu perencanaan, tindakan, observasi, dan 
evaluasi/refleksi (Arikunto, Suhardjono, \& Supardi, 2015). Alokasi waktu pada tiap siklus adalah 7 jam pelajaran. Prosedur penelitian tindakan yang dilakukan ditunjukkan pada Gambar 1.

Desain penelitian tindakan yang dilakukan ditunjukkan pada Gambar 1.

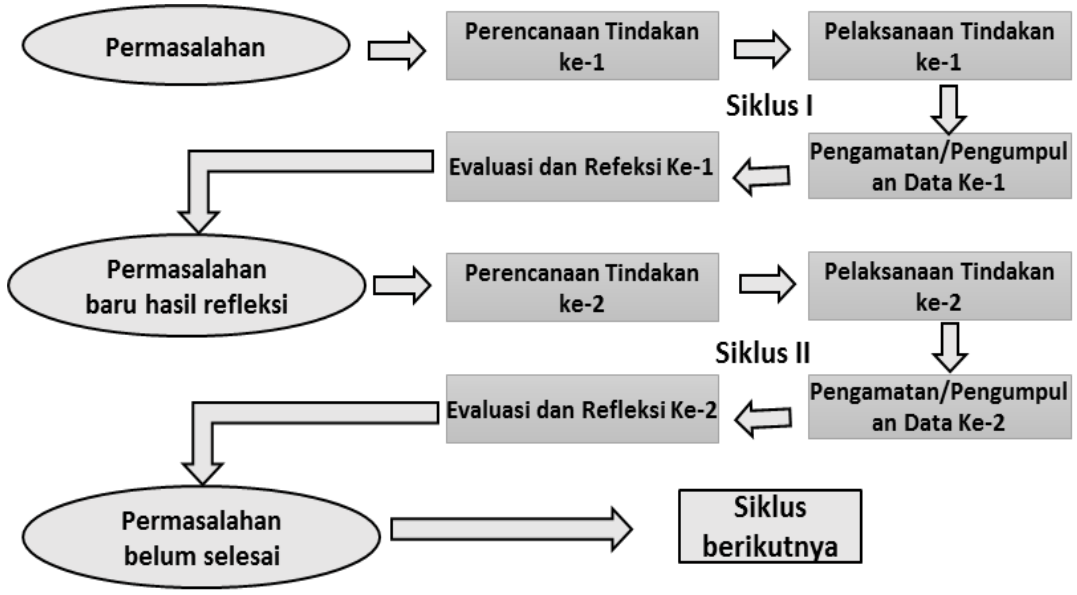

\section{Gambar 1.}

Desain Penelitian

Deskripsi kegiatan penelitian pada siklus 1 diuraikan sebagai berikut.

\section{Perencanaan}

Perencanaan pada siklus 1 disusun berdasarkan masalah yang dijumpai pada pembelajaranprasiklus. Kegiatan yang dilakukan pada tahap perencanaan antara lain.

a. Menyusun perangkat pembelajaran atau rencana pelaksanaan pembelajaran (RPP).

b. Menyusun lembar kerja (LK).

c. Menyusun instrumen penilaian.

d. Menyiapkan media, alat, dan bahan yang dibutuhkan untuk kegiatan pembelajaran.

\section{Pelaksanaan}

Pada tahap ini, peneliti menerapkan pembelajaran EDP-Problem Solving Project pada RPP dengan topik pencemaran air dibantu dengan Lembar Kerja 1. Membuat Alat Penyaring Air Sederhana. Kegiatan pembelajaran pada siklus 1dilaksanakan sebanyak 3 (tiga) kali pertemuan, 
2 (dua) pertemuan untuk pembelajaran dan 1 (satu) pertemuan untuk pelaksanaan tes. Pertemuan ke-1 dilaksanakan pada tanggal 21 Februari 2019, pertemuan ke-2 dilaksanakan pada tanggal 27 Februari 2019, dan Pertemuan ke-3 dilaksanakan pada tanggal 28 Februari 2019. Pada pertemuan ke-1, tahapan pembelajaran EDP-Problem Solving Project yang dilakukan antara lain tahap ask (merumuskan pertanyaan), imagine (membayangkan solusi), dan plan (merencanakan pemecahan masalah). Pada pertemuan ke-2, kegiatan pembelajaran EDP-Problem Solving Project dilanjutkan ketahap Creat, Test, Analyze, Conlude, Communicate, dan Improve. Pada pertemuan ke-3 siswa diberikan tes untuk mengukur pencapaian keterampilan berpikir kritis siswa. Deskripsi dari masingmasing tahap kegiatan disajikan pada Tabel 1.

Tabel 1.

Deskripsi Kegiatan EDP-Probelm Solving Project

\begin{tabular}{|c|c|c|}
\hline No & Tahap & Deskripsi Kegiatan \\
\hline 1 & Ask (bertanya) & $\begin{array}{l}\text { Siswadiajak melakukan observasi masalah lingkungan. Siswa } \\
\text { mencatat masalah yang dijumpai, kemudian siswa diminta } \\
\text { memilih salah satu masalah yang ditemukan dan } \\
\text { merumuskannyadalam bentuk kalimat pertanyaan. }\end{array}$ \\
\hline 2 & $\begin{array}{l}\text { Imagine } \\
\text { (membayangkan) }\end{array}$ & $\begin{array}{l}\text { Siswamembayangkanbeberapasolusiuntukmenyelesaikanmas } \\
\text { alah yang telahdirumuskan. }\end{array}$ \\
\hline 3 & $\begin{array}{l}\text { Plan } \\
\text { (merencanakan) }\end{array}$ & Siswamerencanakankebutuhanalat, bahan, dan desainsolusi. \\
\hline 4 & Creat (membuat) & $\begin{array}{l}\text { Siswa merangkai alat dan bahan untuk mewujudkan } \\
\text { ide/alat/solusipenyelesaianmasalah. }\end{array}$ \\
\hline 5 & $\begin{array}{l}\text { Test } \\
\text { (mengujicobakan) }\end{array}$ & $\begin{array}{lcc}\text { Siswa menguji ide/alatpenyelesaianmasalah } & \text { dan } \\
\text { mengumpulkan data percobaan. } & \end{array}$ \\
\hline 6 & $\begin{array}{l}\text { Analyze } \\
\text { (menganalisis) }\end{array}$ & Siswa menganalisis data percobaan \\
\hline 7 & $\begin{array}{l}\text { Conclude } \\
\text { (menyimpulkan) }\end{array}$ & $\begin{array}{l}\text { Siswa menyimpulkan apakah ide/alatpenyelesaianmasalah } \\
\text { dapat berfungsi dengan baik atau tidak. }\end{array}$ \\
\hline 8 & $\begin{array}{l}\text { Communicate } \\
\text { (mengomunikasika } \\
\mathrm{n} \text { ) }\end{array}$ & $\begin{array}{l}\text { Siswa mengomunikasikan hasil proyek penyelesaian } \\
\text { masalah. }\end{array}$ \\
\hline 9 & $\begin{array}{l}\text { Improve } \\
\text { (mengembangkan) }\end{array}$ & Siswa memperbaiki ide/solusi/alatyang telah dibuat. \\
\hline
\end{tabular}




\section{Observasi}

Pada tahap ini, peneliti melakukan pengumpulan data untuk memdapatkan gambaran keterampilan berpikir kritis dan penyelesaian masalah siswa setelah mengikuti pembelajaran yang dirancang. Keterampilan berpikir kritis siswa dikumpulkan melalui tes. Sedangkan keterampilan penyelesaian masalah dikumpulkan menggunakan lembar observasi dan rubrik penilaian.

\section{Refleksi}

Pada tahap ini peneliti melakukan refleksi atau penilain terhadap berbagai aspek pembelajaran untuk melihat beberapa kekurangan pelaksanaan tindakan pada siklus 1 . Refleksi didasarkan pada hasil observasi. Pada tahap ini juga peneliti melakukan diskusi dengan guru observer untuk mendapatkan saran perbaikan sebagai dasar penyusunan rencana pada siklus 2 .

Kegiatan penelitian pada siklus 2 diuraikan sebagai berikut.

\section{Perencanaan}

Perencanaan pada siklus 2 disusun berdasarkan hasil refleksi pada siklus 1 . Kegiatan yang dilakukan pada tahap perencanaan antara lain.

a. Memperbaiki perangkat pembelajaran atau rencana pelaksanaan pembelajaran (RPP).

b. Memperbaiki lembar kerja (LK) yang telah dibuat.

c. Memperbaiki instrumen penilaian pada siklus 2 .

d. Menyiapkan media, alat, dan bahan yang dibutuhkan untuk kegiatan pembelajaran pada siklus 2 .

\section{Pelaksanaan}

Pada taha pini, peneliti menerapkan pembelajaran EDP-Problem Solving Project pada topik pencemaran udara menggunakan RPP siklus 2 dan Lembar Kerja 2. Penanggulangan Pencemaran Udara. Kegiatan pembelajaran pada siklus 2 dilaksanakan sebanyak 3 (tiga) kali pertemuan, 2 (dua) pertemuan untuk pembelajaran dan 1 (satu) pertemuan untuk pelaksanaan tes. Pertemuan ke-1 dilaksanakan pada 
tanggal 14 Maret 2019, pertemuan ke-2 dilaksanakan pada tanggal 20 Maret 2019, dan Pertemuan ke-3 dilaksanakan pada tanggal 21 Maret 2019. Pada pertemuan ke-1, tahapan pembelajaran EDP-Problem Solving Project yang dilakukan antara lain tahap ask, imagine, dan plan. Pada pertemuan ke-2, kegiatan pembelajaran engineering design process dilanjutkan ke tahap creat, test, analyze, conlude, communicate, dan improve Pada pertemuan ke-3 siswa diberikan tes untuk mengukur pencapaian keterampilan berpikir kritis.

\section{Observasi}

Pada tahap ini, peneliti melakukan pengumpulan data untuk mendapatkan gambaran keterampilan berpikir kritis dan penyelesaian masalah. Keterampilan berpikir kritis siswa dikumpulkan melalui tes. Sedangkan keterampilan penyelesaian masalah dikumpulkan menggunakan lembar observasi dan rubrik penilaian.

\section{Refleksi}

Pada tahap ini peneliti melakukan refleksi atau penilain terhadap berbagai aspek pembelajaran untuk melihat beberapa kekurangan pelaksaan tindakan pada siklus 2. Refleksi didasarkan pada hasil observasi. Pada tahap ini juga peneliti melakukan diskusi dengan guru observer untuk mendapatkan saran perbaikan. Jika indikator kinerja penelitian belum tercapai di akhir siklus 2 akan dilanjutkan pada perencaanaan siklus 3 .

Instrumen pengumpulan data yang digunakan untuk mengumpulkan data penelitian meliputi lembar soal tes, lembar observasi, dan rubrik penilaian. Lembar soal tes digunakan untuk mengumpulkan data kemampuan berpikir kritis pada materi pencemaran lingkungan. Lembar soal pada masing-masing siklus terdiri dari 6 butir uraian. Lembar observasi dan rubrik digunakan untuk mengambil data keterampilan penyelesaian siswa.

Data keterampilan berpikir kritis dan penyelesaian masalah dianalisis secara deskriptif komparatif, yaitu dengan membandingkan 
kondisi awal (prasiklus) dengan hasil belajar siklus 1, membandingkan hasil belajar siklus1 dengan hasil belajar siklus 2, dan membandingkan kondisi awal menganalisis dengan hasil belajar siklus 2. Data deskripsi yang dibandingkan meliputi rata-rata nilai dan persentase siswa yang mencapai target ketuntasan minimal (nilai 70). Adapun indikator keberhasilan penelitian tindakan dirumuskan sebagai berikut.

a. Meningkatknya rata-rata keterampilan berpikir kritis siswa dari 49,06 menjadi 70,00.

b. Meningkatnya jumlah siswa yang mencapai nilai minimal keterampilan berpikir kritis $(\mathrm{KKM}=70)$ dari $6 \%$ menjadi $70 \%$ dari jumlah seluruh siswa.

c. Nilai rata-rata keterampilan penyelesaian masalah mencapai 70,00. Jumlah siswa yang mencapai nilai keterampilan penyelesaian masalah sama dengan 70 mencapai $70 \%$.

\section{Hasil dan Pembahasan}

\section{Peningkatan Keterampilan Berpikir Kritis}

Keterampilan berpikir kritis dapat dilihat dari beberapa aspek atau indikator. Indikator berpikir kritis yang digunakan Sastrika, Sadia, \& Muderawan (2013) di antaranya adalah menafsirkan (interpretasi), menganalisis, mengevaluasi, menyimpulkan (inferensi), dan memberikan penjelasan (eksplanasi). Herayanti \& Habibi (2015) mengungkapkan indikator keterampilan berpikir kritis yang terdiri dari kemampuan menemukan persamaan dan perbedaan, kemampuan memberikan alasan, kemampuan membuat kesimpulan, dan kemampuan menggunakan prinsip yang dapat diterima. Redhana (2017) menyebutkan tujuhi ndikator keterampilan berpikir kritis, yaitu (1) menentukan ungkapan yang ekuivalen atau menentukan contoh dan non contoh, (2) memberi alasan, (3) menerapkan prinsip utama, (4) mengidentifikasi atau menangani hal yang tidak relevan, (5) mencari persamaan dan perbedaan, (6) menentukan ide utama, dan (7) menarik simpulan.

Indikator keterampilan berpikir kritis dalam penelitian ini meliputi aspek memberikan penjelasan (eksplanasi), menafsirkan 
Dani Setiawan

(interpretasi), menganalisis, mebuat kesimpulan (inferensi), dan mengevaluasi. Perumusan indikator tiap aspek keterampilan berpikir tersebut disesuaikan dengan materi pokok materi yang menjadi fokus penelitian tindakan, yaitu materi pencemaran lingkungan dan upaya penanggulangannya.

Penerapan tindakan pembelajaran EDP-Problem Solving Project pada siklus 1 dan siklus 2 dapat membantu meningkatkan keterampilan berpikir kritis seperti terlihat pada Gambar 2, Gambar 3, dan Gambar 4.

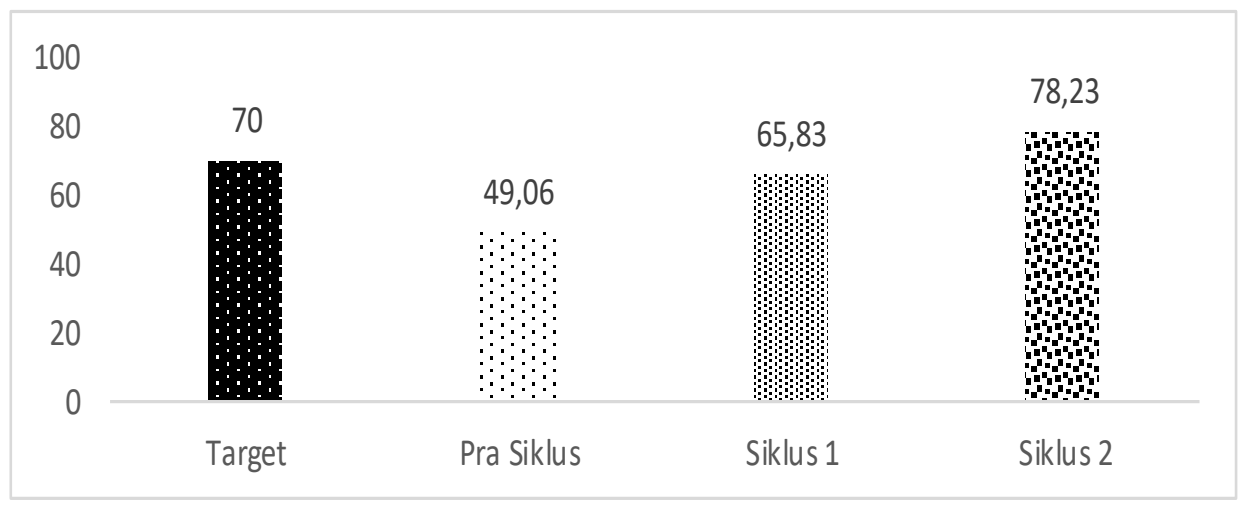

Gambar 2.

Grafik Rata-rata Nilai Keterampilan Berpikir Kritis

100,00

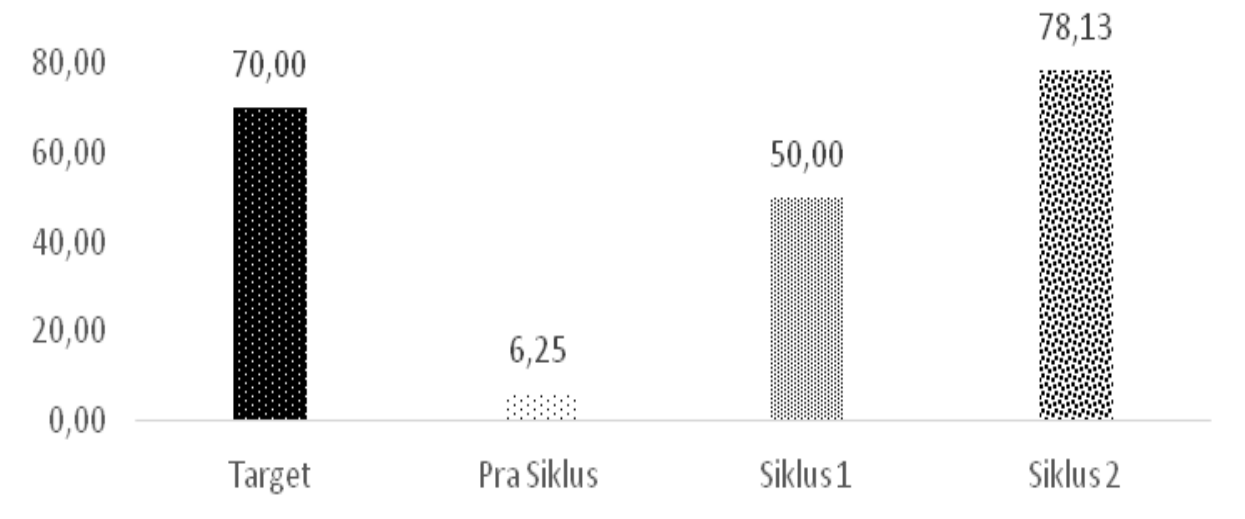

Gambar 3. 


\section{Grafik Persentase Jumlah Siswa Yang Mencapai Target Nilai Keterampilan Berpikir Kritis}
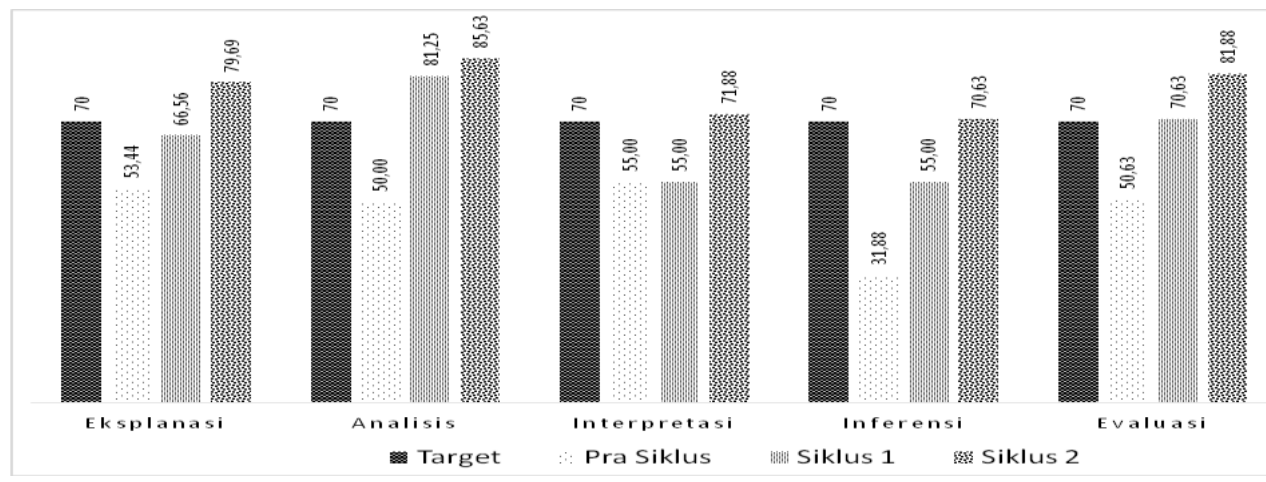

Gambar 4.

\section{Grafik Ketercapaian Keterampilan Berpikir Kritis tiapAspek}

Berdasarkan grafik yang disajikan pada Gambar 2 dapat diketahui bahwa rata-rata keterampilan berpikir kritis siswa mengalami peningkatan dari 49,06 pada pra siklus menjadi 65,83 pada siklus 1 dan 78,23 pada siklus 2. Kemudian berdasarkan grafik pada Gambar 3 diketahui bahwa persentase jumlah siswa yang mencapai target nilai keterampilan berpikir kritis juga mengalami peningkatan, dari 6,25\% pada pra siklus menjadi $50 \%$ pada siklus 1 dan $78,13 \%$ pada siklus 2 . Adapun ketercapaian berpikir kritis pada tiap aspek yang disajikan pada Gambar 4 menunjukkan adanya peningkatan keterampilan berpikir kritis siswa pada tiap aspek. Namun demikian, jika memperhatikan ketercapaian target pada tiap siklus dapat diketahui bahwa target baru tercapai setelah siklus 2 .

Salah satu faktor yang menyebabkan belum tercapainya target pada siklus 1 di antaranya adalah penerapan pembelajaran EDP-Problem Solving Project relatif baru bagi siswa di kelas VII.A SMPN 1 Bulakamba. Selain itu, masih ada beberapa aspek yang perlu mendapatkan perhatian lebih yaitu aspek eksplanasi, interpretasi, dan inferensi. Aspek keterampilan berpikir kritis tersebut pada siklus 1 masih belum mencapai 
target. Oleh karena itu, pada siklus 2 dilakukan perbaikan dengan memberikan penekanan pada aspek tersebut, terutama pada tahap imagine, test, analyze, dan conclude. Pada tahap imagine, saat siswa memberikan alasan pemilihan solusi siswa didorong agar dapat memberikan alasan sesuai masalah dan solusi yang dipilih. Kemudian pada tahap test analyze, dan conclude saat siswa menuliskan data hasil uji coba, siswa diminta untuk menganalisis, menafsirkan data dengan kalimat sendiri, dan membuat kesimpulan yang sesuai dengan masalah yang dicari solusinya dan hasil uji coba yang dilakukan.

Langkah perbaikan yang dilakukan peneliti pada siklus 2 berdampak positif terhadap peningkatan pencapaian nilai keterampilan berpikir kritis siswa secara keseluruhan. Aspek keterampilan berpikir kritis yang belum mencapai target pada siklus 1, yaitu aspek eksplanasi, interpretasi, dan inferensi juga mengalami peningkatan dan mencapai nilai sesuai target yang ditetapkan.

Keberhasilan penerapan pembelajaran EDP-Problem Solving Project dalam meningkatkan keterampilan berpikir kritis pada siswa kelas VII.A SMPN 1 Bulakamba ini karena dalam aplikasi praktis pembelajaran mengimplementasikan unsur pembelajaran EDP, PBL, dan PjBL. Hasil implementasi ini sejalan dengan beberapa hasilpenelitian lain. Hasil studi Berland, Steingut, \& Ko (2014), Sutia \& Mahdalena (2017), dan Syukri, Soewarno, Halim, \& Mohtar (2018) yang menunjukkan bahwa penerapan pembelajaran EDP dapat membantu mengembangkan kemampuan siswa dalam menyelesaikan permasalahan. Pembelajaran EDP memiliki struktur penyelesaian masalah (Sutia \& Mahdalena, 2017) yang dapat dapat membantu siswa mengembangkan keterampilan berpikir kritis dalam menyelesaikan masalah yang dihadapi. Penerapan PBL dalam studi Herzon, Budijanto, \& Utomo (2018) dan Ningsih, Hidayat, \& Kusairi (2018) terbukti dapat membantu siswa dalam meningkatkan kemampuan 
berpikir kritis. Pratama \& Prastyaningrum (2016) dan Hikmah, Budiasih, \& Santoso (2016) melaporkan bahwa penerapan PjBL berpengaruh terhadap peningkatan kemampun berpikiri kritis siswa.

\section{Peningkatan Keterampilan Penyelesaian Masalah}

Keterampilan penyelesaian masalah dapat dilihat dari kemampuan individu melakukan tahapan penyelesaian masalah sebagai indikator. Silaban (2014) mengungkapkan proses penyelesaian masalah ditempuh melalui lima tahap, yaitu: (1) pengumpulan data, (2) menemukan masalah, (3) menemukan gagasan, (4) menemukan jawaban, dan (5) menemukan penerimaan. Sementara Sujarwanto, Hidayat, \& Wartono (2014) mengemukakan lima langkah penyelesaian masalah yaitu (1) memvisualisasikan masalah (visualize the problem), (2) mendeskripsikan masalah (describe the problem), (3) merencanakan solusi (plan the solution), (4) melaksanakan solusi (execute the plan), serta (5) mengecek dan mengevaluasi solusi (check and evaluate).

Indikator penyelesaian masalah yang digunakan oleh Syafii \& Yasin (2013) antara lain (1) kemampuan mengidentifikasi masalah, (2) kemampuan untuk memperoleh data, (3) kemampuan untuk merencanakan solusi permasalahan, (4) kemampuan untuk melaksanakan rencana untuk memecahkan masalah, dan (5) kemampuan untuk mengevaluasi proses pemecahan masalah. Sutia dan Mahdalena (2017) mengungkapkan kemampuan merancang suatu pemecahan masalah meliputi lima tahapan utama yaitu: kemampuan mengidentifikasi masalah, kemampuan menentukan solusi, kemampuanmendesain model prototipe alat, kemampuan membuat model prototipe alat, dan kemampuan mendesain ulang.

Penerapan pembelajaran EDP-Problem Solving Projec pada siklus 1 dan siklus 2 juga dapat membantu siswa meningkatkan keterampilan menyelesaikan masalah pencemaran lingkungan pertanian. Pencapaian nilai keterampilan penyelesaian masalah pencemaran lingkungan pertanian dari 6 kelompok menggunakan rubrik keterampilan penyelesaian masalah disajikan pada Gambar 5, Gambar 6, dan Gambar 7. 


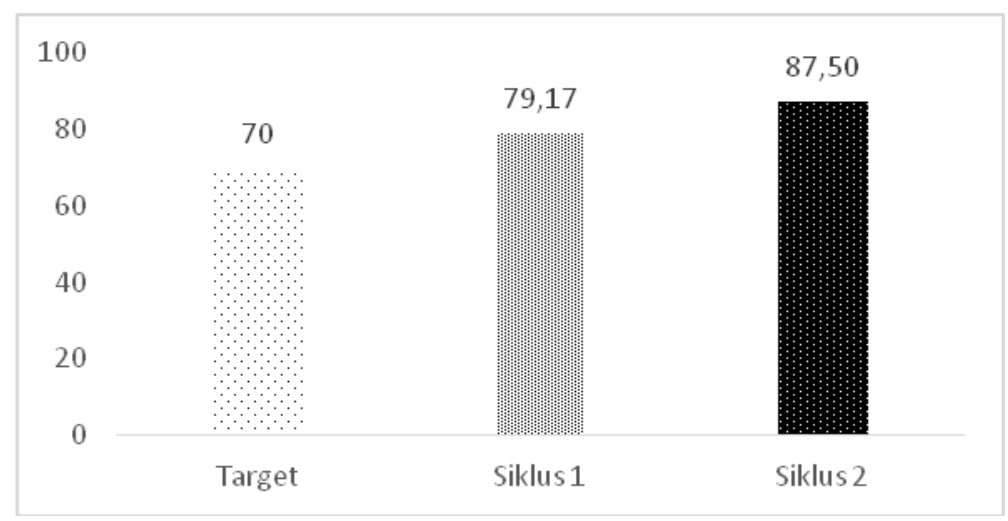

Gambar5.

Grafik Rata-rata Nilai KeterampilanPenyelesaianMasalah

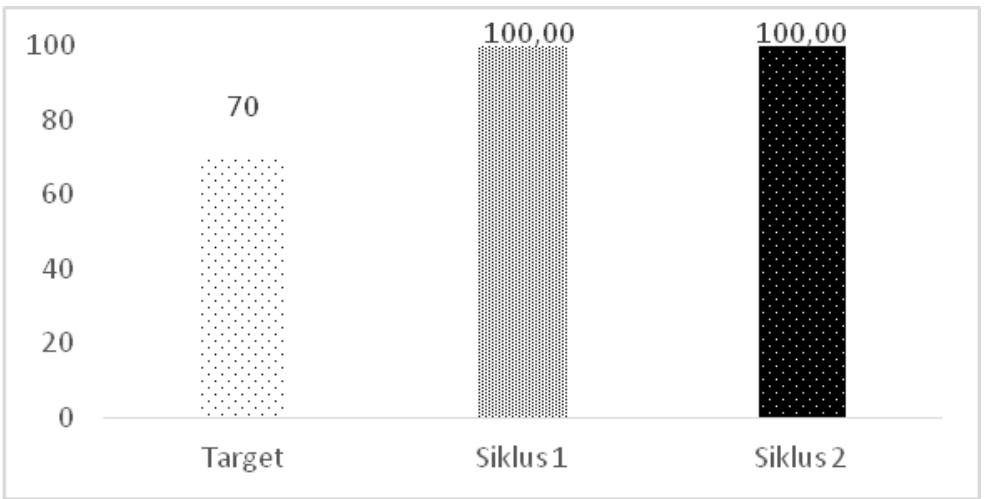

Gambar 6.

GrafikPersentasi Jumlah Kelompok Siswa yang Mencapai Target Nilai Keterampilan Penyelesaian Masalah

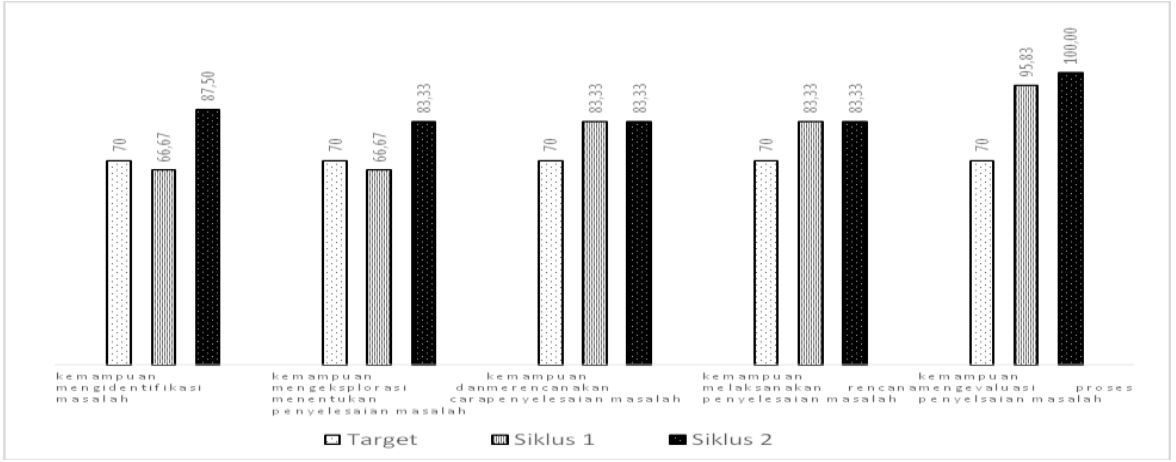

Gambar 7.

Grafik Ketercapaian Keterampilan Penyelesaian pada tiap Aspek 
Berdasarkan grafik yang disajikan pada Gambar 5 dapat diketahui bahwa rata-rata keterampilan penyelesaian siswa mengalami peningkatan dari 79,17 pada siklus 1 menjadi 87,50 pada siklus 2. Kemudian berdasarkan grafik pada Gambar 6 diketahui bahwa persentase jumlah kelompok siswa yang mencapai target nilai keterampilan penyelesaian masalah sudah mencapai $100 \%$ pada siklus 1 . Namun demikian, pada siklus 1 masih ada indikator keterampilan penyelesain masalah yang belum tercapai, yaitu(1) kemampuan mengidentifiksi masalah dan kemampuan mengeksplorasi dan (2) menentukan cara penyelesaian masalah (Gambar 7).

Langkah perbaikan yang dilakukan untuk membantu siswa mengembangkan kemampuan mengidentifikasi, mencatat masalah yang dijumpai, dan merumuskan masalah dalam bentuk kalimat pertanyaan adalah dengan menambahkan ruang (space) khusus untuk menuliskan rumusan masalah yang akan ditulis dalam bentuk kalimat pertanyaan pada tahap ask. Kemudian untuk memudahkan siswa dalam menentukan cara penyelesaian masalah, siswa diarahkan untuk mencari informasi dari berbagai sumber, seperti dari buku literatur di perpustakaan atau mencari informasi dari internet. Langkah ini disampaikan pada bagian penutup sesi pembelajaran. Langkah perbaikan yang dilakukan ini berdampak positif terhadap peningkatan indikator penyelesaian masalah tersebut.

Keberhasilan penerapan pembelajaran EDP-Problem Solving Project dalam meningkatkan keterampilan penyelesaian masalah pencemaran lingkungan pertanian pada siswa kelas VII.A SMPN 1 Bulakamba ini sejalan dengan beberapa hasil penelitian lain. Hasil studi Berland, Steingut, \& Ko (2014), Sutia \& Mahdalena (2017), dan Syukri, Soewarno, Halim, \& Mohtar (2018) yang menunjukkan bahwa penerapan pembelajaran EDP dapat membantu mengembangkan kemampuan siswa dalam menyelesaikan permasalahan.

Pembelajaran EDP memiliki struktur penyelesaian masalah yang dapat menuntun siswa menjadi perancang penyelesai masalah melalui 
proses menganalisis masalah, mensintesis sumber dan informasi ke dalam penyelesaian masalah, dan mengevaluasi penyelesaian masalah (Sutia \& Mahdalena, 2017). Hasil penelitian Simamora, Sidabutar, \& Surya (2017) dan Sagala, Rahmatsyah, \& Simanjuntak (2017) menunjukkan bahwa penerapan PBL dapat meningkatkan kemampuan siswa dalam menyelesaikan masalah. Purnomo \& Mawarsari (2014) melaporkan bahwa penerapan PjBL dapat membantu siswa dalam meningkatkan kemampuan menyelesaikan masalah.

\section{Penutup}

Berdasarkan hasil dan pembahasan dapat disimpulkan bahwa (1) keterampilan berpikir kritis dan (2) Keterampilan penyelesaian masalah pencemaran lingkungan pertanian pada siswa kelas VII.A SMPN 1 Bulakamba dapat ditingkatkan melalui penerapan pembelajaran EDPProblem Solving Project. Beberapa hal yang perlu ditekankan pada saat mengimplementasikan EDP-Problem Solving Project untuk mendapatkan dampak yang optimal guru perlu memberikan perhatian lebih pada tahap ask pada saat siswa merumuskan masalah dalam bentuk kalimat tanya. Guru perlu memberikan pertnyaan pemancing yang dapat menginsporasi siswa dalam merumsukan pertanyaan.

Selain itu perlu ada penelitian lanjut untuk melihat dampak pembelajaran EDP-Problem Solving Projectpada kemampuan berkolaborasi dan berkomunikasi.

\section{Ucapan Terimakasih}

Penulis mengucapkan terimakasih kepada Kepala SMP Negeri 1 Bulakamba, Ibu Ening Ambarwati, S.Pd.,M.M. Penulis juga mengucapkan kepada Guru IPA di SMP Negeri 1 Bulakamba: Bpk. Sumarno, S.Pd.,M.M., Ibu Dian Lestari, M.Pd., Ibu Sjamsiatun Sjah, S.Pd., Ibu Cipta Restu Aruni, S.Pd., dan semua pihak yang telah memberikan bantuan serta saran perbaikan selama melakukan penelitian. 


\section{Daftar Referensi}

Arikunto, S., Suhardjono, \& Supardi. (2015). Penelitian Tindakan Kelas. Jakarta: Bumi Aksara.

Berland, L., Steingut, R., \& Ko, P. (2014). High School Student Perceptions of the Utility of the Engineering Design Process: Creating Opportunities to Engage in Engineering Practices and Apply Math and Science Content.Journal of Science Education and Technology (J Sci Educ Technol), 705-720.

Fuad, N. M., Zubaidah, S., Mahanal, S., \& Suarsini, E. (2015). Profil Hasil Belajar, Keterampilan Berpikir Kritis dan Kreatif Siswa serta Strategi Pembelajaran yang Diterapkan Guru SMP di Kabupaten Kediri. Prosiding Seminar Nasional Biologi dan Pembelajarannya (hal. 807-8015). Malang: Jurusan Biologi FMIPA UM.

Fuad, N. M., Zubaidah, S., Mahanal, S., \& Suarsini, E. (2017). (2017). Improving Junior High Schools' Critical Thinking Skills Based on Test Three Different Models of Learning. International Journal of Instruction, 10(1), 101-116.

Häkkinen, P., Järvelä, S., Mäkitalo-Siegl, K., Ahonen, A., Näykki, P., \& Valtonen, T. (2016). . Preparing Teacher-students for Twentyfirstcentury Learning Practices (PREP 21): A Framework for Enhancing Collaborative Problem-solving and Strategic Learning Skills. Teacher and Teaching theory and practice, 1-17.

Herayanti, L., \& Habibi. (2015). Model Pembelajaran Berbasis Masalah Berbantuan Simulasi Komputer Untuk Meningkatkan Keterampilan Berpikir Kritis Calon Guru Fisika. Jurnal Pendidikan Fisika dan Teknologi, 1(1), 61-66.

Herzon, H. H., Budijanto, \& Utomo, D. H. (2018). Pengaruh Problem-Based Learning (PBL) terhadap Keterampilan Berpikir Kritis. Jurnal Pendidikan: Teori, Penelitian, dan Pengembangan, 3(1), 42-46.

Hikmah, N., Budiasih, E., \& Santoso, A. (2016). Pengaruh Strategi Project Based Learning (Pjbl) terhadap Kemampuan Berpikir Kritis Siswa Kelas XI IPA pada Materi Koloid. Jurnal Pendidikan: Teori, Penelitian, dan Pengembangan, 1(11), 2248-2253.

Mahanal, S., Zubaidah, S., Bahri, A., \& Dinnurriya, M. S. (2016). Improving students' critical thinking skills through Remap NHT in biology 
classroom. Asia-Pacific Forum on Science Learning and Teaching, $17(2)$.

Martin, M. O., Mullis, I. V., Foy, P., \& Hooper, M. (2016). TIMSS 2015 International Results in Science. Dipetik May 2, 2019, dari http:/ / timssandpirls.bc.edu:

http://timssandpirls.bc.edu/timss2015/international-results/wpcontent/uploads/filebase/full\%20pdfs/T15-International-Resultsin-Science-Grade-8.pdf

Ningsih, P. R., Hidayat, A., \& Kusairi, S. (2018). Penerapan Problem Based Learning untuk Meningkatkan Kemampuan Berpikir Kritis dan Hasil Belajar Siswa Kelas III. Jurnal Pendidikan: Teori, Penelitian, dan Pengembangan, 3(12), 1587-1593.

Pratama, H., \& Prastyaningrum, I. (2016). Pengaruh Model Pembelajaran Project Based Learning Berbantuan Media Pembelajaran Pembangkit Listrik Tenaga Mikrohidro terhadap Kemampuan Berpikir Kritis. Jurnal Penelitian Fisika dan Aplikasinya (JPFA), 6(2), 44-50.

Purnomo, E. A., \& Mawarsari, V. D. (2014). Peningkatan Kemampuan Pemecahan Masalah Melalui Model Pembelajaran Ideal Problem Solving Berbasis Project Based Learning. Jurnal Karya Pendidikan Matematika (JKPM), 1(1), 25-31.

Redhana, I. W. (2017). Redhana, Model Pembelajaran Berbasis Masalah untuk Peningkatan Keterampilan Pemecahan Masalah dan Berpikir Kritis. Jurnal Pendidikan dan Pengajaran, 46(1), 76-86.

Roekel, D. (2018). Preparing 21st Century Students for a Global Society. Washington, D.C.: National Education Association.

Sagala, N. L., Rahmatsyah, \& Simanjuntak, M. P. (2017). The Influence of Problem Based Learning Model on Scientific Process Skill and Problem Solving Ability of Student. IOSR Journal of Research \& Method in Education (IOSR-JRME), 7(4), 01-09.

Sastrika, I. A., Sadia, I. W., \& Muderawan, I. W. (2013). PENGARUH MODEL PEMBELAJARAN BERBASIS PROYEK TERHADAP PEMAHAMAN KONSEP KIMIA DAN KETERAMPILAN BERPIKIR KRITIS. e-Journal Program Pascasarjana Universitas Pendidikan Ganesha Program Studi IPA, 3(2). 
Silaban, B. (2014). Hubungan antara Penguasaan Konsep Fisika dan Kreativitas dengan Kemampuan Memecahkan Masalah pada Materi Pokok Listrik Statis. Jurnal Penelitian Bidang Pendidikan Vol. 20 No. 1, 65-75.

Simamora, R. E., Sidabutar, D. R., \& Surya, E. (2017). Improving Learning Activity and Students' Problem Solving Skill through Problem Based Learning (PBL) in Junior High School. International Journal of Sciences: Basic and Applied Research (IJSBAR), 33(1), 321-331.

Siswanto, R., Sugiono, S., \& Prasojo, L. (2018). The Development of Management Model Program of Vocational School Teacher Partnership with Business World and Industry Word (DUDI). Jurnal Ilmiah Peuradeun, 6(3), 365-384. doi:10.26811/peuradeun.v6i3.322

Suarsana, I. M., \& Mahayukti, G. (2013). Pengembangan E-Modul Berorientasi Pemecahan Masalah Untuk Meningkatkan Keterampilan Berpikir Kritis Mahasiswa. Jurnal Pendidikan Indonesia, 2(2), 264275.

Sujarwanto, E., Hidayat, A., \& Wartono. (2014). Kemampuan Pemecahan Masalah Fisika pada Modelling Instruction pada Siswa SMA Kelas XI. Jurnal Pendidikan IPA Indonesia Volume 3 No. 1, 65-78.

Sutia, C., \& Mahdalena, M. (2017). Motivasi Belajar Siswa SMA dan Kemampuan Merancang Pemecahan Masalah Lingkungan melalui Pembelajaran Engineering Design Process. Seminar Penelitian Bidang IPA 2017 (hal. 32-40). Bandung: SEAMEO Regional Centre for QITEP in Science.

Syafii, W., \& Yasin, R. M. (2013). Problem Solving Skills and Learning Achievements through Problem-Based Module in Teaching and Learning Biology in High School. Asian Social Science Vol. 9 No. 12, 220-228.

Syukri, M., Soewarno, S., Halim, L., \& Mohtar, L. (2018). The Impact of Engineering Design Process in Teaching and Learning to Enhance Students' Science Problem-Solving Skills. Jurnal Pendidikan IPA Indonesia (JPII), 7(1), 66-75.

Trilling, B., \& Fadel, C. (2009). 21st Century Skills: Learning for Life in Our Times. Amerika: JosseyBass Wiley. 